\title{
POLA KOMUNIKASI TRADISI MAROSOK ANTARA SESAMA PENJUAL DALAM BUDAYA DAGANG MINANGKABAU
}

\author{
Samia Fadhilah ${ }^{1}$ dan Evie Ariadne Shinta Dewi ${ }^{2}$ \\ ${ }^{1} \mathrm{CV}$. Tria Adijaya \\ ${ }^{2}$ Universitas Padjadjaran
}

\begin{abstract}
ABSTRAK
Penelitian ini bertujuan untuk untuk memahami pola komunikasi tradisi marosok antara sesama penjual dalam budaya dagang Minangkabau. Pendekatan yang digunakan dalam penelitian ini adalah kualitatif dengan studi etnografi komunikasi. Subjek penelitian adalah para penjual ternak di Balai Cubadak. Subjek dipilih secara purposive sampling (sampel bertujuan) dengan jumlah 6 orang. Data penelitian diperoleh melalui wawancara mendalam, observasi, dokumentasi, studi pustaka. Adapun teknis analisis dengan mengumpulkan data, mendeskripsikan, menganalisis, dan melakukan interpretasi. Hasil penelitian menunjukan bahwa peristiwa komunikasi diantara sesama penjual yaitu (1) menanyakan harga (2) memberikan nasihat (3) berdiskusi mengenai pengalaman bertransaksi. Peristiwa terjadi diparkiran, los, dan warung. Pesan disampaikan bernada santai menggunakan bahasa Minangkabau baik verbal dan non verbal, dilandaskan kepada norma dan nilai luhur yang telah diwariskan dari generasi kegenerasi lainnya, meskipun beberapa tradisi mulai ditinggalkan. Pola komunikasi tradisi marosok antara sesama penjual dalam budaya dagang minangkau dibentuk atas dasar kesadaran untuk menjaga silaturahmi melalui forum diskusi antara sesama penjual, keharusan mewariskan nilai-nilai dan membantu sesama. Oleh karena itu, semua penjual berpartisipasi aktif menuangkan semua pengalaman yang didapatkan selama bertransaksi dan kemudian dibagi ke forum, dan mengambil pelajaran. Pelajaran inilah yang kemudian digunakan sebagai landasan bertindak dalam berdagang di kemudian hari.
\end{abstract}

Kata-kata Kunci: Komunikasi, bisnis, budaya, perdagangan, tradisi

\section{COMMUNICATION PATTERNS OF MAROSOK AMONG SELLERS IN MINANGKABAU TRADING CULTURE}

\begin{abstract}
This study aimed to understand communication patterns among sellers marosok tradition in the culture of Minangkabau trade. The approach used in this study is a qualitative ethnographic study of communication. The subject of research is the seller in Balai Cubadak. Subjects selected by purposive sampling by the number 6. Data were obtained through interviews, observation, documentation, literature. The technical analysis of the collected data, describe, analyze, and do the interpretation. The results showed that the events of communication amongst sellers are, (1) asking price (2) advise (3) discuss the transaction experience. Event occurs at parking area, animal stalls, and coffe shop. The aim is to additionally received information, interpersonal needs, establish yourself as a person Minangkabau identity, and to influence the worldview of other sellers. Messages delivered using Minangkabau languagewith relaxed tone both verbal and nonverbal, is based the norms and noble values that passed from generation to another generation, although some traditions began to be abandoned. Communication patterns of Marosok tradition among sellers in cullture of Minangkabau trading formed on the basis of awareness to keep in touch in discussion forum among the seller, the obligation to pass on the values and helping others. Therefore, all sellers participating actively sharing all the experience acquired during the transaction and then divided into forums, and take a lesson. The lesson is then used as the basis for action in the trade in the future.
\end{abstract}

Keywords: Communication, bussiness, culture, trade, tradition

Korespondensi: Samia Fadhilah, M.I.Kom. CV. Tria Adijaya, Jl. Batik Jogja No.51 Bandung 42123. Email: samiasaibah@gmail.com 


\section{PENDAHULUAN}

Menjaga hubungan yang harmonis adalah sebuah kewajiban dalam adat Minangkabau. Hubungan yang baik harus dijaga dalam berbagai sisi kehidupan baik dalam sosial, politik, pendidikan, dan perdagangan. Bahkan demi terciptanya hubungan yang harmonis dalam perdagangan di Minangkabau dibuatlah sebuah tradisi yang dikenal dengan Tradisi Marosok. Menurut Datuak Lelo Kayo sebagai salah satu pimpinan suku di Minangkabau Marosok merupakan tradisi turun temurun untuk mencegah terjadinya perselisihan antara pembeli, antar penjual maupun diantara pembeli dan penjual. Lebih jauh lagi Marosok merupakan tradisi tawar menawar hewan ternak menggunakan jari-jari, setiap jari melambangkan angka tertentu. Untuk menjaga kerahasiaan permainan jari antara pembeli dan penjual yang sedang tawar menawar maka jarijari akan ditutup dengan handuk, sarung atau jaket (Wawancara, Datuak Lelo Kayo 15 Juli 2015).

Tradisi Marosok dilakukan disemua pasar ternak yang ada di Minangkabau, yang dikenal dengan sebutan balai. Ada tujuh balai yaitu Palangki, Koto Baru, Sungai Sariak, Muaro Paneh, Payakumbuah, dan Cubadak, semua balai tersebut melaksanakan Marosokdalam jual beli hewan (Fahlevi: 2015). Menurut Datuak Lelo Kayo marosok sudah dijalankan turun-temurun dari generasi kegenerasi, semua balai ternak melaksanakannya. Tradisi ini masih dipertahankan karena karena nilai manfaat nya yang sangat besar, dimana tidak ada persaingan harga antara pembeli ataupun penjual hingga terciptalah perdangan yang sehat (Wawancara, Datuak Lelo Kayo 15 Juli 2015).

Balai bisa menyediakan 300 sapi dan kerbau serta 100 kambing. Hewan tersebut dari berbagai jenis dan berbagai tempat baik dari Sumatera Barat, Indonesia. Salah satu balai yang terkenal karena jumlah hewan ternanya banyak adalah Balai Cubadak, selain itu letaknya berada ditengah-tengah ibu kota pemerintahan kerajaan Minangkabau dahulu kala. Sehingga nilai luhur dalam tradisi masih dijaga menurut beberapa orang penjual sapi.

Penjagaan terhadap tradisi lah yang membuat Cubadak sedikit berbeda dengan balai yang lain. Tapi selebihnya prosesi nya masih sama dari mulai menerka berat sapi hingga akhir jual menjual sapi terjadi. Proses dibagi menjadi tiga tahapan, tahapan pertama dimulai dengan menerka berat sapi. Sapi diterka beratnya bukan ditimbang, sehingga pembeli dituntut memiliki kemampuan menerka dengan benar jika tidak ingin rugi. Memiliki kemampuan dan keahlian berarti pembeli harus memiliki pengalaman yang banyak dalam menerka berat badan hewan.

Tahapan kedua adalah prosesi Marosok yang merupakan tawar menawar harga hewan ternak. Tahapan diawali dengan mencari pemilik sapi, kemudian berjabat tangan. Seperti yang telah dijelaskan di atas untuk menjaga kerahasiaan jabat tangan ini harus ditutup dengan sarung, jaket atau handuk. Dalam jabat tangan ini kedua belah pihak mulai memainkan jari-jari tangan mereka. Setiap jari-jari, lekukan jari, ayunan menyimbolkan makna tertentu. Tidak ada komunikasi verbal dalam tawar menawar tersebut.

Setiap balai memiliki hari dagang masingmasing. Balai Cubadak misalnya buka setiap hari Kamis mulai dari jam 7.00 hingga jam 13.00. Hanya ada satu hari dalam seminggu. Hanya hari pada hari Jum'at saja balai tidak beroperasi, hal ini menurut Pak Del hari Jumat harinya pendek, hari jumaik ko urang ka jumaik, alun jadi baharago beko lah azan. Hari jum'at dianggap pendek karena lelaki yang menjadi pelaku dalam tradisi marosok, akan melaksanakan sholat Jum'at. Pelaksanaan sholat jum'at memakan waktu lebih sari satu jam. Sehingga berkemungkinan besar tenak mereka dipasar tidak akan ada yang menjaga, sehingga balai di hari Jum'at ditiadakan (Wawancara dengan Pak Del 10 Agustus 2016).

Komunikasi memegang peranan penting dalam Tradisi Marosok di Balai Cubadak. Komunikasi terjadi diantara penjual dan pembeli, sesama pembeli dan sama penjual. Namun peneliti tertarik untuk meneliti komunikasi yang terjadi antara sesama penjual yang terlibat tradisi marosok, karena beberapa penelitian terdahulu sudah mengkaji pola-pola komunikasi yang terjadi antara penjual dan pembeli, tapi tidak ada yang menggali pola komunikasi antara sesama penjual. Bagaimana kemudian aspek verbal dan non-verbal terlibat dalam peristiwa-peristiwa komunikasi antara sesama penjual bisa saja menjadi landasan dalam bertransaksi nantinya. Hubungan dagang dalam tradisi marosok menurut Datuak Lelo Kayo bukan hanya sekedar dagang yang 
memberikan keuntungan materi, didalam nya ada keuntungan dalam berelasi, keuntungan yang dihasilkan dari menghindari pertikaian, keuntungan dalam menjaga silaturahmi. Semua keuntungan itu bisa didapat dengan tetap teguh menjalankan apa yang telah diturunkan oleh nenek moyang. Hal ini akan dikaji nantinya melalui sudut pandang sesama penjual.

Pendekatan etnografi komunikasi yang dipakai oleh peneliti fokus pada kajian perilaku komunikasi verbal dan nonverbal yang mencakup bahasa dan budaya dalam trasaksi perdagangan ternak yang dilakukan antara sesama penjual di Balai Cubadak. Peneliti berusaha menemukan peristiwa serta komponen komunikasi yang diterapkan oleh penjual hewan ternak di Balai Cubadak. Dengan demikian, pentingnya untuk dikaji "pola komunikasi tradisi marosok antara sesama penjual dalam budaya dagang Minangkabau.

Adapun fokus penelitian ini adalah "bagaimana pola komunikasi tradisi marosok antara sesama penjual dalam budaya dagang Minangkabau?". Untuk lebih menguraikan masalah dalam penelitian ini, maka pertanyaanpertanyaan penelitian ini adalah sebagai berikut: (1) Bagaimana peristiwa komunikasi yang terjadi secara berulang (recurent events) diantara sesama penjual dalam tradisi Marosok di Balai Cubadak? (2) komponen komunikasi apa saja yangada dalam tradisi Marosok di Balai Cubadak yang membentuk peristiwaperistiwa komunikasi tersebut? (3) Bagaimana pola hubungan antar komponen komunikasi yang terjadi diantara sesama penjual dalam tradisi Marosok di Balai Cubadak?

Tujuan dilaksanakannya penelitian ini adalah untuk memahami pola komunikasi tradisi marosok antara sesama penjual dalam budaya dagang Minangkabau. Diawali dengan memahami peristiwa komunikasi yang terjadi secara berulang (recurent events) diantara sesama penjual dalam tradisi Marosok di Balai Cubadak, kemudian menganalisis komponenkomponen yang ada, selanjutnya menemukan pola hubungan antara komponen-komponen tersebut.

Penelitian ini diharapkan memberikan sumbangan pengetahuan, acuan, dan rujukan dalam mengembangkan ilmu komunikasi, khusunya tentang etnografi komunikasi dalam kajian pola komunikasi bisnis yang ditemukan pada tradisi marosok dalam budaya dagang
Minangkabau, terkhususnya komunikasi yang terjadi antara sesama penjual. Penelitian ini juga diharapkan dapat menjadi rujukan bagi penjual dan pembeli ternak di Minangkabau untuk meningkatkan perdagangan hewan di Sumatera Barat melalui budaya Marosok . Penelitian ini juga dapat menjadi referensi bagi masyarakat umum yang ingin mengetahui nilainilai penting dalam budaya Marosok .

Istilah etnografi berasal dari ethno (bangsa) dan graphy (menguraikan), jadi etnografi yang dimaksud adalah usaha untuk menguraikan kebudayaan atau aspek- aspek kebudayaan (Maleong, 1990: 13). Etnografi komunikasi pertama kali diperkenalkan oleh Dell Hymes 1962, karena dia menilai selama ini ilmu linguistik hanya memperhatikan fisik bahasa nya saja. Pertama kali Hymes memperkenalkan the Etnography Speaking (etnografi bahasa), sebagai sebuah pendekatan baru yang berfokus pada pola perilaku komunikasi sebagai salah satu komponen penting dalam sistem kebudayaan, dan pola ini kemudian berfungsi diantara konteks budaya yang holistik, dan berhubungan dengan pola komponen sistem lain (Kuswarno, 2012: 13).

Etnography Speaking atau etnografi berbicara kemudian lebih dikenal dengan nama etnografi komunikasi. Perubahan nama menjadi etnografi komunikasi dikarenakan Hymes yang memiliki anggapan bahwa yang menjadi kerangka acuan untuk memberikan tempat bahasa dalam suatu kebudayaan haruslan difokuskan kepada komunikasi bukan pada bahasa. Dell Hymes (1962) mengungkapkan bahwa ada delapan unsur dalam sebuah peristiwa etnografi komunikasi dengan konsep yang ia sebut dengen SPEAKING: (1) Setting and scene menurut Hymes berkaitan dengan ruang dan waktu dimana hal itu akan mempengaruhi aktivitas komunikasi atau situasi pembicaraan, (2) Participant. Partisipan adalah para pihak yang terlibat dalam sebuah peritiwa tutur, (3) End adalah maksud dan tujuan dari pembicaraan yang dilakukan. Banyak alasan mengapa orang melakukan peristiwa tutur, (4) Act sequences. Bagian ini mengacu kepada kalimat atau bahasa yang digunakan, (5) Key. Istilah ini sering dikaitkan dengan nada kalimat, (6) Instrumentalities atau instrumen adalah alat atau media yang digunakan, (7) Norm, Norma atau tata laku yang berlaku di masyarakat akan dipengaruhi tata bahasa dan kalimat yang 
digunakan pada saat orang berinteraksi dengan bahasa, dan (8) Genre. Genre adalah bentuk penyampaian, apakah bentuk narasi, khutbah, dll.

Hymes lebih lanjut dalam Kuswarno (2012: 37) mengemukakan tahapan-tahapan untuk melakukan penelitian etnografi komunikasi dalam suatu masyarakat tutur harus melalui tiga tahapan yaitu: Identifikasi peristiwa komunikasi yang terjadi secara berulang, Inventaris komponen komunikasi yang membangun peristiwa komunikasi yang berulang tersebut, dan temukan hubungan antar komponen komunikasi yang membangun peristiwa komunikasi tersebut.

Dengan demikian, teori etnografi komunikasi digunakan untuk melihat peristiwa komunikasi yang terjadi selama interaksi antara penjual dalam tradisi marosok. Peristiwa komunikasi dalam tradisi Marosok akan diuraikan ke dalam delapan unsur yaitu setting, participant, end, act sequences, key instrumentalities, norm, genre. Selanjutnya peneliti peneliti berusaha untuk menemukan pola komunikasi dengan menghubungkan komponen-komponen komunikasi dalam Tradisi Marosok.

Identitas merupakan konsep yang abstrak kompleks, dan dinamis. Ting-Tomey dalam Samovar (2010) mengatakan bahwa identitas sebagai konsep diri yang direfleksikan atau gambaran diri bahwa kita bersal dari keluarga, gender, budaya, etnis, dan proses sosialisasi individu. Sehingga identitas budaya adalah rasa kepemilikan seseorang terhadap budaya atau kelompok tertentu, sehingga identitas merupakan persamaan perbedaan (Charon dan Vigilant, 2008: 31)

Stuart Hall dalam karyanya Cultural Identy and Diaspora (1990), berpendapat bahwa konsep identitas budaya memiliki duca cara pandang, pertama sebagai as being kedua becoming. Konsep pertama cara pertama dalam melihat identitas budaya adalah melihatnya sebagai suatu yang esensial. Identitas budaya dipandang sebagai sesuatu yang tidak akan berubah. Menurut Hall, identitas budaya dalam cara ini merefleksikan pengalaman sejarah dan kode-kode kebudayaan dari mereka yang menciptakan, sebagaimana individu yang sama, stabil dan tidak pernal berubah (Hall, 1990: 223).

Konsep kedua becoming, dalam cara pandang ini Stuart Hall tidak lagi melihat budaya sebagai suatu yang esensialis, melainkan sesuatu yang akan selalu berubah setiap saat. Identitas budaya dalam konsep ini mempermasalahkan bagaimana proses "menjadi" sama pentingnya dengan apa yang telah terjadi. It is matter of "becoming" as well as of "being". It belong to the future as much as to the past. It is not something which already exist, transcending place, time, history and culture (Hall, 1990: 225). Menurut Hall dalam kutipan tersebut, identitas budaya bukan hanya merujuk pada masa lalu saja, melainkan apa yang ada pada masa kini dan masa depan. Hal tersebut karena proses "becoming" identitas akan terjadi terus menerus sesuai dengan tempat, waktu, sejarah, dan budaya. Hall menegaskan bahwa identitas budaya bukanlah sesuatu yang kaku dan tidak berubah dari waktu ke waktu, melainkan identitas budaya adalah sesuatu yang terus menerus dibentuk berdasarkan kerangka sejarah dan budaya.

Demikian pula halnya dengan tradisi marosok, tidak bisa dipungkiri bahwa seiring perubahan zaman, identitas dagang masyarakat minangkabau bisa saja berubah sedikit-demi sedikit, meskipun pada taraf yang esensi masih bertahan. Perubahan ini bisa saja dikarenakan karena adanya tekanan secara internal maupun eksternal. Komunikasi bisnis melibatkan berbagai macam bentuk komunikasi baik verbal maupun komunikasi nonverbal untuk mencepai tujuan tertentu (Purwanto, 2006: 3). Dalam komunikasi bisnis diperlukan komponenkomponen komunikasi yaitu sumber, pesan, dan penerima (Curtis, 2005: 6). Baik sumber maupun penerima harus saling memahami pesan verbal, non verbal, serta simbol-simbol yang dikirimkan (Curtis, 2005: 8).

Kemampuan dalam berkomunikasi sangat penting dalam berbisnis karena berpengaruh terhadap kemampuan beradaptasi, dengan memahami hubungan antar personal akan meningkatkan kemampuan seseorang sebagai komunikator bisnis (Curtis 2005: 30). Komunikasi antarpersonal dalam komunikasi bisnis memiliki komponen penting yaitu konsep diri, hubungan, dan keterbukaan. Adapun fungsi atau tujuan dilaksanakannya komunikasi secara umum menurut Samovar (2010: 16-17) pertama adalah untuk mencari informasi informasi. Kedua untuk memenuhi kebutuhan interpersonal melalui percakapan. 
Ketiga membentuk identitas diri melalui interaksi bersama dalam kelompok. Keempat untuk mempengaruhi orang lain.

Jika ditarik keranah bisni maka secara umum ada tiga tujuan komunikasi bisnis yaitu: memberi informasi, melakukan persuasi, dan melakukan kolaborasi dengan audience. (Purwanto, 2006: 71). Tujuan informasi adalah tujuan yang berkaitan dengan pemberian informasi mengenai dunia bisnis kepada pihak lain. Tujuan persuasi adalah agar pihak lain memahami apa yang disampaikan dengan baik dan benar. Persuasi sering dilakukan pada saat negosiasi antara seseorang dengan orang lain dalam bisnis. Tujuan kolabirasi adalah melakukan kerjasama dengan orang lain, sehingga dicapainya tujuan bersama.

Kaitan komunikasi bisnis dengan objek yang diteliti adalah untuk melihat interaksi sesama penjual dari sudut pandang komunikasi bisnis. Bagaimana kemudian penjual melibatkan dirinya dalam kelompok bisnis untuk menciptakan identitas diri melalui diskusi-diskusi sesama pedagang, mendapatkan informasi untuk berinterkasi. Selain itu juga dilihat keterbukaan dan penerimaaan masingmasing penjual yang terlibat saat diskusi berlangsung.

Pesan verbal adalah semua jenis simbol yang menggunakan satu kata atau lebih (Mulyana, 2012: 260), sedangkan pesan nonverbal adalah secara sederhana semua isyarat yang bukan kata (Mulyana, 2012: 343). Setiap budaya memiliki pesan verbal dan non verbal yang berbeda-beda bergantung kepada nilainilai yang dianut (Wood, 2009: 169), yang kemudian menjelaskan keadaan sosial dan emosi dari hubungan dan interaksi (Morreale, 2007: 113), bahkan untuk sebuah komunitas dance memiliki gaya berkomunikasi verbal dan non verbal yang mereka sepakati (Supratman \& Rafiqi, 2016). Demikian pula halnya dengan tradisi marosok. sebagai sebuah komunikasi bisnis, tradisi ini memiliki pesan verbal dan non-verbal. Simbol-simbol baik verbal dan nonverbal yang memiliki makna tertentu bagi penjual hewan ternak, setiap penjual harus mahaminya, karena jika tidak maka komunikasi tersebut dianggap gagal. Sehingga meneliti konsep verbal dan non verbal dalam tradisi marosok sangatlah penting.

Inti penting dari budaya adalah pandangan yang bertujuan untuk mempermudah hidup dengan "mengajarkan" orang-orang bagaimana caraberadaptasidengan lingkungannya(Triandis dalam Samovar, 2010: 27). Hal ini melibatkan pengetahuan yang dibutuhkan orang supaya mereka dapat berperan aktif dalam lingkungan sosialnya (Spitzberg dalam Samovar dan Porter, 2009: 281). Budaya memiliki beberapa elemen seperti sejarah, agama, nilai, organisasi sosial, dan bahasa (Huntington dalam Samovar, 2010: 31). Samovar (2010: 31-48) juga menyebutkan tidak hanya elemen tapi budaya juga memiliki karakteristik. Karakteristik pertama budaya itu dipelajari baik secara formal maupun non formal, melalui dongeng, cerita, dan legenda. Kedua, budaya itu dibagikan melalui keluarga, pertemanan, dan institusi keagamaan. Ketiga budaya diturunkan dari generasi kegerasi. Keempat budaya didasarkan pada simbol, melalui simbol menurut Ferraro (2008: 29) simbol merupakan pengingikat bagi kelompok yang bersatu. Simbol budaya dapat berupa bentuk, gerakan, objek, bendera, ikon keagamaan, dan sebagainya (Samovar, 2010: 45). Kelima budaya itu dinamis karena dia adalah proses penciptaan oleh karena itu dia akan terus memodifikasi dirinya. Keenam budaya adalah sistem yang terintegrasi dengan sistem-sistem yang ada disekelilingnya.

Kaitan budaya dengan objek yang dikaji adalah bagaimana kemudian tradisi Marosok sebagai sebuah bagian budaya terus dilestarikan dan diwariskan dari generasi kegenerasi selanjutnya melalui berbagai pengajaran non formal yang melibatkan ide, bahasa, dan simbol-simbol tertentu didalamnya. Selain itu peneliti berusaha untuk melihat bagaimana kemudian marosok berkaitan dengan sistem adat dan agama yang ada di Minangkabau, melalui petatah-petitih yang diturunkan dari generasi ke generasi.

\section{METODE PENELITIAN}

Penelitian ini menggunakan metode kualitatif deskriptif. Riset ini betujuan untuk menjelaskan pola komunikasi tradisi Marosok antar sesama penjual di Balai Cubadak. Peneliti berusaha memahami fenomena tentang apa yang dialami oleh penjual hewan ternak di Balai Cubadak, misalnya interaksi, perilaku, peristiwa komunikasi yang terkait dengan budaya Marosok. Metode kualitatif bersifat deskriptif yang tujuan utamanya adalah mencoba untuk 
memperoleh gambaran yang lebih mendalam (Kriyantono, 2006: 58) mengenai tradisi Marosok diantara sesama penjual hewan ternak di Balai Cubadak.

Penelitian ini menggunakan paradigma atau pendekatan penelitian etnografi komunikasi, yakni sebuah penerapan dari metode etnografi pada pola-pola atau cara berinterakasi atau berkomunikasi dalam setiap peristiwa komunikasi sesama penjual di Balai Cubadak. Hal ini sesuai dengan karakteristik etnografi komunikasi yang berupaya untuk memolakan, menggambarkan, menganalisis, dan menjelaskan perilaku komunikasi dari suatu kelompok sosial.

Seville-Troike (dalam Kuswarno, 2012: 15) menyatakan bahwa yang menjadi fokus kajian etnografi komunikasi adalah masyarakat tutur. Hal ini sangat sejalan dengan pendekatan penelitian kualitatif. Dimanadidalammasyarakat mencakup (a) cara-cara bagaimana komunikasi itu dipola dan diorganisasikan sebagai sebuah sistem dari peristiwa komunikasi (b) cara-cara bagaimana pola komunikasi itu hidup dalam interaksi dengan komponen sistem kebudayaan lain. Berdasarkan penjelasan tersebut maka peneliti berusaha untuk memahami bagaimana komunikasi antara sesama penjual hewan ternak di Balai Cubadak kemudian dipola dan diorganisasikan sebagai sebuah sistem dari peristiwa komunikasi.

Penelitian ini menggunakan metode etnografi komunikasi yang dianggap paling tepat untuk menganalisis bahasa budaya dan komunikasi dalam tradisi Marosok Balai Cubadak. Seperti yang telah dijelaskan oleh Dell Hymes (dalam Kuswarno, 2012: 37) tahapan yang harus dilalui dalam penelitian etnografi komunikasi adalah identifikasi peristiwa-peristiwa komunikasi yang terjadi secara berulang (current event) antara sesama penjualyang terjadi dalam tradisi Marosok Balai Cubadak, (2) inventarisasi komponen komunikasi yang membangun peristiwa komunikasi yang berulang tersebut dalam tradisi Marosok, (3) temukan pola hubungan antara komponen komunikasi yang membangun peristiwa komunikasi, yang dikenal kemudian dengan pemolaan komunikasi (communication patterning), yang melibatkan sesama penjual hewan ternak tradisi marosok.

Pada penelitian etnografi komunikasi, yang menjadi fokus perhatian adalah perilaku komunikasi dalam tema kebudayaan tertentu (dalam konteks penelitian ini, yakni perilaku sesama penjual. Namun tidak semua perilaku adapaun yang dimaksud dengan perilaku komunikasi menurut Ilmu Komunikasi adalah tindakan atau kegiatan seseorang, kelompok, yang terlibat dalam proses komunikasi (Kuswarno, 2012: 35). Jadi yang akan dilihat nantinya adalah perilaku sesama penjual ketika terlibat dalam proses komunikasi.

Teknik pengumpulan data yang dilakukan adalam penelitian ini adalah. Pertama, teknik observasi yaitu pengamatan secara langsung perilaku dan interaksi komunikasi yang terjadi diantara sesama penjual. Kedua, wawancara mendalam yang dilakukan di sela-sela istirahat para penjual hewan ternak biasanya ketika jadwal makan siang, dilakukan secara berulang sehingga data dianggap lengkap. Untuk melengkapi data peneliti juga mewawancarai tetua adat dan budayawan, yang dinilai mampu menjelaskan tradisi marosok dari sudut pandang adat dan ideologi Minangkabau. Ketiga, Studi dokumentasi yang berkaitan dengan tradisi marosok, sejarah, penyebaran hewan ternak. Selain itu peneliti juga mendokumentasikan melalui vidio dan foto yang dapat dijadikan pendukung.

Metode analisis data diawali dengan deskripsi objek penelitian secara mendetail terkait dengan komunikasi antara sesama penjual dalam tradisi marosok. Kemudian setelah data dideskripsikan maka selanjutnya peneliti menganalisis dara tersebut sesuai dengan arah fokus penelitian yaitu pola komunikasi tradisi marosok antara sesama penjual dalam budaya dagang minangkabau, sehingga peneliti dapan menjelaskan pola-pola komunikasi yang terjadi. Tahap akhir dalam menganalisis data adalah dengan melakukan interpretasi dimana peneliti mengambil kesimpulan dari analisis yang telah dilakukan.

\section{HASIL DAN PEMBAHASAN}

Hasil penelitian ini mencakup tiga pokok permasalahan yakni peristiwa komunikasi, komponen, dan pola hubungan antara komponen-komponen yang ada dalam peritiwa komunikasi antara sesama penjual hewan ternak dalam tradisi marosok di Balai Cubadak. Ketiga pokok bahasan tersebut akan diuraikan berurutan disertai dengan modelnya. 
Sebagaimana Kuswarno (2012: 42) menyatakan bahwa peristiwa komunikasi merupakan seluruhan perangkat komponen utuh yang melibatkan partisipan, dimulai dengan tujuan umum komunikasi, topik varietas bahasa tone, dan kaidah bahasa yang sama. Adapun peristiwa-peristiwa yang terjadi antara sesama penjual dapat dikategorikan dalam tiga tujuan yaitu tujuan untuk menanyakan harga, memberikan nasihat, dan diskusi mengenai pengalaman bertransaksi.

Menanyakan harga memiliki kaidah tertentu yaitu dengan menggunakan kodekode tertentu yaitu dengan menggunakan jarijari, yang telah disepakati oleh nenek moyang. Tujuannya adalah agar tidak terjai permainan harga yang nantinya ditakutkan akan meluas kepada pertikaian. Kaidah menghindari konflik telah ditanamkan oleh nenek moyang dimana orang Minangkabau meyakini bahwa musuh pantang untuk dicari, jika bertemu jangan dilewatkan (Wawancara Datuak Lelo Kayo 15 Juli 2016). Penggunaan kode yang telah peneliti sebelumnya adalah adalah salah satu cara untuk mencari musuh kaidah inilah yang kemudian disebut dengan identity as being menurut Hall (Hall, 1990: 225), dimana bentuk seseorang hari ini akan sama dengan leluhurnya, orang Minangkabau hari ini sama dengan nenek moyang nya sama-sama tidak pernah ingin mencari lawan. Meskipun demikian beberapa orang tidak menggunakan kode tersebut, namun mereka berusaha untuk tidak mencari lawan dengan memanas-manasi harga lebih murah. Penggunaan kode diantara sesama penjual mulai berkurang dikarenakan penggunaan kode tidak efisien menurut beberapa orang, jika seseorang tidak mengerti kode yang disampaikan kode tersebut bisa ditafsirkan dalam banyak makna.

Diskusi mengenai pengalaman bertransaksi merupakan ajang untuk mendapatkan informasi perdagangan. Dalam diskusi setiap partisipan menggunakan nada yang santai karena ditakutkan akan memancing emosi orang lain. Berbicang dalam kelompok juga memiliki kaidah tertentu, setiap perkataan harus diperhatikan sebagai mana yang disampaikan oleh pepatah Minangkabau bajalan paliharo kaki, bakato peliharo lidah (KKM, 2010: 8). Setiap perkataan yang akan disampaikan dalam berdiskusi harus dipikirkan terlebih dahulu, mengingat dalam diskusi tersebut melibatkan banyak pihak yang mungkin saja tidak terlalu akrab.

Cara berdiskusi juga harus diperhatikan, mengingat banyak nya partisipan yang tentunya juga terdiri dari berbagai usia. Cara bicara kepada usia tententu juga diatur oleh adat Minangkabau, kepada yang tua menggunakan kato mandaki yaitu tutur hormat, kepada yang muda menggunakan kato manurun yaitu menggunakan nada kasih sayang, dan kato mandata yaitu cara tutur kepada yang sebaya (Pandoe, 2010: 236).

Peristiwa lain yang sering terlihat adalah tetua atau senior yang berpengalaman dalam berjualan akan membagi pengalamanya dalam bentuk nasihat kepada yang lebih muda. Sebagaimana yang telah penulis sebutkan sebelumnya nasihat disampaikan dengan menggunakan kato manurun (Pandoe, 2010: 236). Nasihat yang diberikan cukup beragam, salah satunya adalah dalam berdagang harus punya prinsip jujur, pandangan ini didapatkan berdasarkan berpuluh tahun bergelut dibidang jual-beli hewan ternak, orang yang tidak jujur harta nya tidak akan berkah, hanya akan menggiring kepada kesengsaraan hidup di dunia dan di akhirat (Wawancara Mak Mantarin 24 Agustus 2016). Hal ini sejalan dengan landasan gerak masyarakat Minangkabau yaitu kitabullah atau Al-Quran (Hakimy, 1994: 16). Prinsip ini membentuk identitas budaya para penjual hewan ternak, karena dia selalu diajarkan oleh generasi sebelumnya (Samovar, 2010: 32), diwariskan dari generasi kegenerasi lain (Brislin, 1993: 6). Semua peristiwa dilaksanakan tidak hanya atas dasar mencari keuntungan semata tetapi juga menjadi silaturahmi antara sesama pedagang. Silaturahmi menurut masyarakat Minangkabau silaturahmi menjadi wajib.

Berdasarkan peristiwa tersebut peneliti kemudian menginventarisasi komponenkomunikasi yang membangun pertiwa komunikasi yang berulang tersebut (Kuswarno, 2012: 37). Sebagaimana yang dipaparkan oleh Dell Hymes (1972: 59-65) komponen komunikasi terdiri dari (S) Setting, (P) Participant, (E) End, (A) Act Sequence, (K) Key, (I) Instrumentalities, (N) Norm, (G) Genre. Adapun komponen peristiwa komunikasi diantara sesama penjual hewan ternak juga akan dinalisis menggunakan komponen SPEAKING.

Setting merupakan tempat atau lokasi pelaksanaan dalam suatu peristiwa komunikasi, adapun yang menjadi lokasi peristiwa 
komunikasi antara sesama penjual adalah parkiran, los, sekitar warung dan warung. Jika hujan turun lebat maka semakin banyak yang berdiskusi, karena pada saat hujan turun jarang terjadi transaski, untuk mengisi waktu luang penjual biasanya berdiskusi dengan sesama penjual. Participant yang terlibat adalah para penjual yang semuanya adalah laki-laki. Menurut Pak Sun budaya Marosok hanya berkembang di kaum laki-laki, alasan kenapa hanya berkembang dengan laki-laki sampai saat ini belum diketahui (Wawancara dengan Pak Sun 22 Agustus 2016).

End atau tujuan atau fungsi dari peristiwa komunikasi antara sesama penjual, pertama mencari informasi (Samovar, 2010: 16) mengenai orang lain, harga, dan pengalaman bertransaksi, informasi ini berguna sebagai penntu sikap jika berhadapan dengan orang lain. Kedua memenuhi kebutuhan interpersonal (Samovar, 2010: 17) melalui percakapan yang dilakukan sesama penjual, di dalam percakapan tersebut penjual akan merasakan persahabatan, pelarian, dan solusi kehidupan. Ketiga membetuk identitas diri (Samovar, 2010: 17) melalui nasehat-nasehat yang disampaikan tetua kepada penjual pemula, diwariskan keruhuran budi, kejujuran, dan disimplin dalam berjualan. Semua itu adalah identitas yang harus dimiliki oleh masyarakat Minangkabau. Melalui nasehat juga melahirkan fungsi keempat dari komunikasi yaitu mempengaruhi orang lain (Samovar, 2010: 17) dimana tetua akan mempengaruhi cara pandang pemula dalam berjualan, hingga kedepannya para pemula bisa berjualan dengan jujur.

Selanjutnya komponen Act Sequence merupakan urutan pelaksanaan komunikasi dalam setiap peristiwa komunikasi. Ada 3 peristiwa yang ditemukan dalam interaksi antara sesama penjual seperti yang sudah penulis sebutkan di atas, dan semua peritiwa tersbut diawali dengan bertanya, begitulah cara orang Minangkabau membuka forum.

Komponen Key atau nada suara saat pesan komunikasi ketika sesama penjual bertransaksi dalam morosok. Nada santai begitu terasa dalam setiap ucapan tradisi ini, meskipun ada beberapa nada yang menunjukan perasaan emosional. Setiap penjual tidak kaku dalam menyampaikan pesan, karena mereka meyakini kekakuan akan menimbulkan jarak dan kecurigaan antar sesama. Suasana yang dibuat seakrab mungkin, karena dengan menciptakan keakraban akan lahir saling pengertian dan hubungan yang harmonis. Hubungan yang harmonis diciptakan dari perilaku dan bahasa yang sopan (Samovar 2010: 351).

Komponen Instrumental berkaitan dengan media, saluran, maupun perantara dalam berkomunikasi. Adapun yang menjadi media atau saluran dalam Marosok adalah bahasa baik itu secara verbal maupun non verbal. Samovar (2010: 45) dalam bukunya menyebutkan bahwa aspek penting dari budaya adalah bahasa. Tentunya bahasa yang digunakan dalam tradisi ini adalah bahasa Minang. Didalam bahasa minangkabau termasuk di dalamnya pesan pesan verbal, non verbal. Ada banyak pesan non verbal dalam tradisi Marosok seperti yang digambarkan oleh Gambar 1.
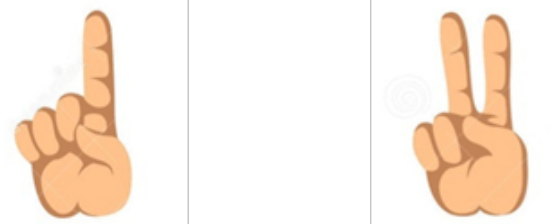

Gambar 1: Jari telunjuk Gambar 2: Jari melambangangkan angka $1,10,100$, $1000,10.000$ biasanya menjadi penanda awal. telunjuk dan jari tengah melambangkan angka 2, 20, 200, 20.000, $200.000,2.000 .000$

Jika 10 juta untuk sapi 1 juta untuk kambing
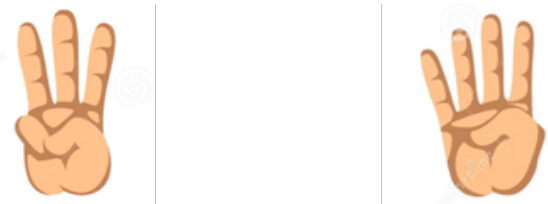

Gambar 3: Jari telunjuk Gambar 4: Jari telunjuk dan jari tengah, jari manis melambangkan angka 3, 30, 300, 30.000, 300.000, 3.000 .000 dan jari tengah, jari manis, dan kelingking melambangkan angka 4, 40, 400, 40.000, $400.000,4.000 .000$
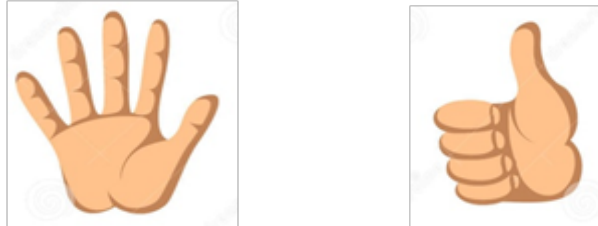

Gambar 5: lima jari melambangkan angka 5, 50, 500, 50.000, Gambar 6: jempol melambangkan angka $500.000,5.000 .000$ 25, 250, 2500, 250.000 $2.500 .000,25.000 .000$ 
Wajah juga menjadi pesan non verbal dalam tradisi Marosok. Wajah menusia mampu menunjukan lebih dari 1000 ekspresi yang berbeda (Wood 2013: 119). Begitu juga dengan budaya Marosok jika dahi berkerut dan menyipitkan mata atau bahkan memejamkan matanya artinya seseorang sedang berpikir atau merenung. Ketidak setujuan bisa dibaca dari gelengan muka, kemarahan bisa diidentifikasi ketika seseorang memalingkan muka ke kiri atau ke kanan sambil mengeluarkan nada mengeluh atau marah. Selain itu ada pesan non verbal lain yang ikut berkontribusi dalam tradisi Marosok yaitu keheningan. Keheningan mengindikasikan banyak makna (Wood 2013: 127). Keheningan dalam tradisi Marosok menggambarkan proses berpikir dan pertimbangan. Bahkan keheningan di Minangkabau bida digolongkan kepada tanda setuju atau sependapat dengan lawan bicara.

Berikutnya komponen yang ada dalam tradisi Marosok lain nya adalah komponen norma. Norma berkaitan dengan kaidah komunikasi atau aturan yang mengatur tradisi Marosok. Norma adalah aturan informal yang memandu bagaimana anggota suatu budaya bertindak, sekaligus bagaimana mereka berpikir dan merasa (Wood 2013: 141). Norma mencerminkan nilai-nilai budaya, begitu juga dengan Marosok, norma-norma yang ada didalamnya menggambarkan nilai-nilai dari budaya Minangkabau. Misalnya saja tata cara berbicara baik seusia kepada yang lebih tua, kepada yang lebih muda maupun kepada yang dihormati. Orang Minangkabau mengkerangkai cara bicara tersebut dalam kato nan ampek (kaya yang empat)yaitu: Katomandaki, Kato manurun, Kato mandata, Kato malereang (Pandoe 2010: 236). Kato mandaki adalah bertutur hormat kepada orang yang lebih tua tua. Kedua, kato malereang yakni bertutur kata kepada ipa-bisan atau rang sumando (menantu), berbicara tidak boleh langsung tapi harus menggunakan kiasan dan kata-kata bijak, agar bisa memberikan pengajaran tanpa harus menyinggung. Ketiga, kato mandata digunakan bila bertutur dengan teman sebaya. Keempat, kato manurun, tutur bernuasa kasih sayang kepada yang lebih muda. Kato mandaki, kato mandata dan kato manurun adalah cara tutur yang paling banyak digunakan dalam tradisi Marosok. Misalnya kato mandaki digunakan untuk berkomunikasi dengan orang yang lebih tua, kato mandata digunakan untuk berkomunikasi dengan sesama penjual dan pembeli yang seusia, sedangkan kato manurun dipergunakan untuk berkomunikasi dengan yang lebih muda. Gaya komunikasi manurun banyak digunakan oleh tetua jika memberikan nasehat kepada penjual maupun pembeli yang masih muda.

Norma lainnya adalah bertutur tidak boleh sembarangan harus dipikirkan terlebih dahulu, harus diperhatikan kata-kata yang menyinggung perasaan orang lain. Hal ini digambarkan dalam pepatah Jan barundiang basikasek, Jan bakato basikasa, Jan babana ka pangka langan, Usah ba-utak ka ampu kaki. Artinya menurut Datuak Lelo Kayo dalam berunding harus saling berlembut hati, jika bertutur gunakan kata-kata yang lembut, jangan sampai menggunakan fisik jika marah. Pergaulan harus mengutamakan keramahan, sopan dan santun, hormat menghormati. Demikian pula adat bergaul di dalam berdagang (Wawancara Datuak Lelo Kayo tanggal 21 Juli 2016).

Komponen selanjutanya adalah genre atau tipe peristiwa dalam tradisi Marosok dapat dibagi ke dalam tiga kategori yaitu gendre tanya jawab, cerita dan nasehat. Rata-rata genre tanya jawab dilakukan diantara sesama penjual untuk mendapatkan informasi. Sedangkan genre cerita digunakam dalam proses bebagi informasi, memecahkan masalah dalam jual beli ternak. Genre nasihat, melalui nasehat seseorang bisa mempersingkat waktu belajar. Ferraro dalam Samovar (2010: 32) mengatakan bahwa tanpa manfaat belajar pada orang hidup sebelum nya hidup akan sulit -kalau tidak mustahil. Melalui nasehat-nasehat tersebut baik penjual maupun pembeli yang lebih muda mewarisi kepercayaan, nilai, norma, bahasa dan budaya Marosok (Wood dalam Samovar 2010: 34). Misalnya prinsip dalam berdagang itu harus jujur harus berani rugi, hal seperti ini sering diajarkan meskipun secara tidak formal.

Sebelumnya peneliti telah menguraikan secara rinci bahwa langkah pertama dalam mendeskripsikan dan analisa pola komunikasi mencakup pengidentifikasian peristiwa yang terjadi secara berulang, langkah selanjutnya adalah menginventarisasi komponen peristiwa komunikasi serta aspek-aspek lain yang ada dalam masyarakat tutur tradisi Marosok. Polapola komunikasi diantara sesama penjual yang ditetapkan berdasarkan pengataan-pernyataan informan dan hasil pengamatan peneliti akan diuraikan sebagai berikut. 
Pengalaman, informasi, dan nasehat disampaikan melalui berbagai cerita baik dari yang muda maupun yang tua didalam kelompok. Komunikasi kelompok dalam tradisi Marosok ini dilakukan untuk berbagi pengalaman, menyempurnakan pekerjaan dan menyelamatkan dari kondisi perdagangan yang bisa merugikan (Hodson \& Sullivan, 2002 dalam Wood 2013: 202). Mungkin para pedagang tidak menyadari, namun peneliti melihat bahwa diskusi ini adalah diskusi yang rutin. Nasihat dan cerita membuat setiap pedagang secara tidak sadar membentuk hubungan ketergantungan. Misalnya saja ketika memutuskan perkara sapi harus dijual kesiapa, maka seorang pedagang akan meminta referensi dari teman-teman mereka, karena kelompok penjual memiliki ide prespektif, pengalaman, dan keahlian yang dituangkan untuk memecahkan masalah. Di sinin terjadi proses pertukaran informasi, adapun setiap individu memiliki kebutuhan informasi yang harus dipenuhi guna kelangsungan kegiatan sehari-hari penggunanya (Hamami, Sinaga, \& Erwina, 2014).

Melalui kelompok para pedagang memiliki kekuatan potensial kelompok,dimana adanya sumberdaya lebih, ketelitian lebih, kreativitas lebih (Wood 2013: 206-207). Setiap anggota kelompokberusaha memberikan saran dan saling melengkapi satu dengan yang lain. Hal ini sesuai dengan filosofi adat Minangkabau: Basilang kayu dalam tungku, Di sinan api mako ka iduik, Di situ nasi mako ka masak. Artinya meskipun orang-orang tersebut memiliki pendapat yang berbeda atau kekurangan pendapat yang bagus, namun setiap anggota berusaha menambahkan, sehingga lahirlah suatu keputusan yang dinilai bagus oleh kelompok.

Para tetua memberikan nasihat karena beliau sadar beliau sudah banyak memiliki pengalaman yang bisa dijadikan oleh pedagang lain sebagai refersi. Sebagaimana pepatah minang menyatakan jauah bajalan banyak diliek, lamo hiduik banyak di raso (jauh berjalan banyak yang dirasa, lama hidup banyak yang dirasa). Tetua yang dari usia sudah lanjut tentunya sudah banyak episode kehidupan yang terlalui, dan sudah banyak pula mendapatkan pengajaran darinya. Menyimpan ilmu dan pelajaran hidup sendiri tentulah tidak berguna. Akan lebih baik jika diceritakan sehingga orang bisa mengambil hikmah dari setiap perjalanan kehidupan. Hal ini sejalan dengan konsep pengalaman komunikasi yang bisa terjadi karena adanya aktivitas komunikasi. Komunikasi adalah pusat paling sentral dalam mempertahankan keberlangsungan hidup individu dan menjalin hubungan antar individu (Nurtyasrini \& Hafiar, 2016).

Karena peristiwa ini banyak bercerita, sehingga sesekali cara penyampaian menggunakan nada santai, berbisik, dan agak tinggi. Cara penyampaian bergantung kepada apa yang sedang diceritakan, jika sesuatu yang rahasia maka pedagang akan sedikit mengecilkan suaranya, jika cerita nasihat maka pedagang akan menyampaikannya dengan santai, namun jika cerita berkaitan dengan perasaaan sakit hati maka penyampaianpesan pun menggunakan nada-nada tinggi dan penuh dengan kiasan. Peristiwa yang dialami tersebut menjadi sebuah engalaman komunikasi yang dilakukan melalui komunikasi transaksional melibatkan pertukaran persepsi hingga ekspektasi antar anggota aktor komunikasi yang kemudian terwujud dalam perilaku yang ditampilkan individu (Utamidewi, Mulyana, \& Rizal, 2017).

Peristiwa komunikasi sesama pembeli melibatkan banyak partisipan, dengan pola interaksi desentralisasi dimana kekuasaan setiap kelompok hampir sama (Wood 2013: 211). Meskipun didalamnya melibatkan para tetua tetapi tidak menutup kemungkinan yang lebih muda mendominasi dan memberikan pandangan. Setiap anggota kelompok tentu saja memiliki aturan tatacara berbicara kepada yang lebih besar, lebih tua dan sama besar. Peraturan komunikasi mengatur baik perilaku verbal maupun non verbal dan metapkan apa yang harus diungkapkan namun juga bagaimana hal tersebut seharusnya diungkapkan (Samovar 2014: 344). Misalnya membicarakan nama orang di forum tidak diperbolehkan.

Tanpa disadari oleh pedagang melalui cerita dan nasihat telah terbentuk hubungan saling ketergantungan, dan didalamnya pedagang mentaati aturan yang sama dalam bercerita dan menasehati. Pedagang akan merasa kekurangan jika tidak ada cerita yang dibagikan oleh kelompok, karena mereka menilai, mereka bisa saja ketinggalan informasi jika tidak bercerita dengan kelompok. Sebagaimana pepatah minang manyatakan Duduak basamo balapang-lapang, Duduak surang basampik 
sampik (KKM 2010: 9)

Artinya ketika seseorang hidup sendiri maka hidupnya akan sempit, jika hidup bersamasama menjaga silatuhami maka hidup akan lapang karena banyak pertolongan dari anggota kelompok, ada banyak saran dan bantuan yang bisa diberikan oleh kelompok. Jika seseorang pedagang hanya mementingkan diri sendiri jarang berkumpul dengan kelompok nya maka bantuan juga akan jarang datang. Bahkan menurut mengamatan peneliti semakin sering seseorang berkumpul dengan kelompoknya dan dia memiliki nilai-nilai kejujuran dalam berdagang, maka kelompok tersebut dengan sukarelah membatunya apabila ada kesulitan. Berdasasarkan uraian diaras komunikasi antar penjual digambarkan oleh Gambar 2.

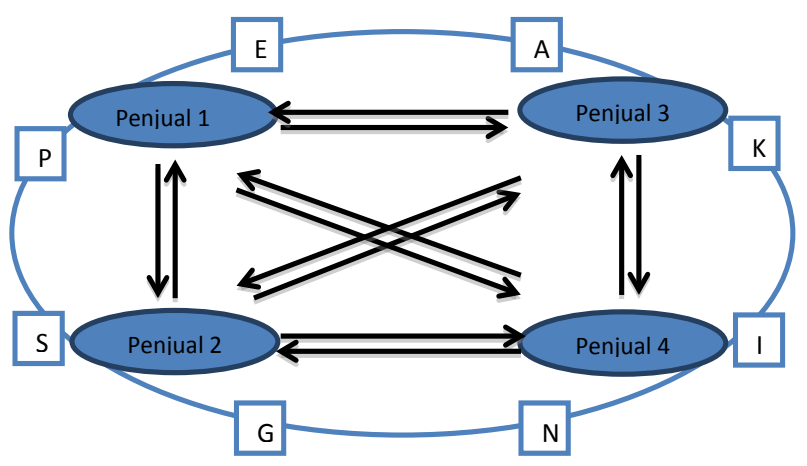

Gambar 2 Peristiwa komunikasi yang terjadi antara sesama penjual hewan ternak di Balai Cubadak Batusangka.

Keterangan: Setiap penjual berinteraksi dengan penjual lainnya

Setting: Di warung, di dekat los, di parkiran dalam suasa santai terdapat interaksi antar pribadi di dalam kelompok dalam membicarakan pedagangan hewan.

Partisipant: Para penjual yang lebih dari dua orang

End: Berbagai penglaman, menambah pengaman, mendapatkan informasi

Act Sequence: Bertanya atau membuka pebiacaraan, diskusi, setiap anggota dikelompok memberikan pendapat dan saran, setiap anggota mendapatkan kesimpulan dari hasil pembicaraan

Key: Santai, bercanda, sesekali nada suara naik Istrumentalities: Menggunakan bahasa Minangkabau dan beberapa kiasan

Norm: Sesuai dengan aturan komunikasi dalam budaya minangkabau cara berbicara kepada yang tua sama besar dan yang kecil harus diperhatikan, perhatikan kata-kata yang akan diucapkan.

Genre: Nasihat dan cerita.

Secara komprehensif pola komunikasi antara sesama penjual tradisi marosok dalam budayda dagang Minangkabau secara etnografi komunikasi, lebih jelasnya dapat dilihat pada Gambar 3.

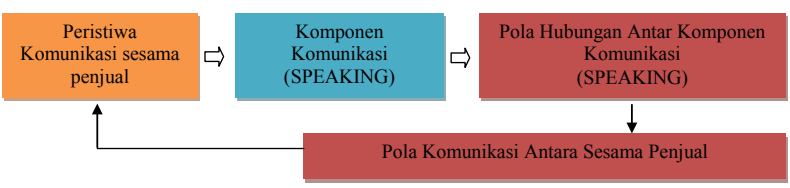

\section{Gambar 3 Peristiwa komunikasi yang terjadi antara sesama penjual hewan ternak di Balai Cubadak Batusangka.}

\section{SIMPULAN}

Tujuan pokok dari penelitian ini adalah untuk mengetahui cara atau pola-pola komunikasi tradisi marosok antara sesama penjual dalam budaya dagang minangkabau dengan menggunakan metode penelitian etnografi komunikasi serta menganalisis peristiwa-peristiwa komunikasi. Selain itu ingin mengetahui komponen-komponen komunimasi dan pola hubungan antar komponen komunikasi sehingga memperoleh pemolaan komunikasi tradisi marosok dalam budaya dagang di Minangkabau. Untuk lebih jelas nya diuraikan sebagai berikut:

Peristiwa-peristiwa komunikasi dalam tradisi marosok yang terjadi diantara sesama penjual dibagi atas tiga peristiwa yaitu (1) Menanyakan harga (2) Memberikan nasihat (3) Berdiskusi mengenai pengalaman bertransaksi. Setiap peristiwa dalam marosok memiliki situasi, partisipan, tujuan, urutan tindak, kunci, instrumen, norma, genre yang telah diwariskan dari generasi ke generasi, dan masih dilaksanakan meskipun pada instrumen bahasabahasa non verbal dalam tradisi marosok sudah mulai ada yang meninggalkanya.

Komponen-komponen komunikasi yang membentuk pola komunikasi tradisi marosok dalam budaya dagang minangkabau: 1. (S) Setting, atau merupakan tempat atau lokasi pelaksanaan marosok adalah parkiran, los, sekitar warung dan warung. Jika turun hujan para penjual akan lebih sering berdikusi karena tidak 
ada orang yang akan menawar ketika hujan, 2 . (P) Participant atau partisipan yang terlibat dalam interaksi antara sesama penjual adalah laki-laki, 3. (E) End atau tujuan dari komunikasi dalam setiap peristiwa komunikasi antar sesama penjual dalam tradisi Marosokadalah mendapatkkan informasi, memenuhi kebutuhan interpesonal, membentuk indentitas diir sebagai orang minang, dan untuk mempengaruhi cara pandang penjual lainnya, 4. (A) Act sequence atau urutan tindakan komunikatif atau tindak tutur termasuk alih giliran atau fenomena percakapan sesama penjual selalu diawali dengan bertanya untuk membuka forum, 5. (K) Key atau nada yang digunakan dalam marosok adalah nada santai, meskipun ada beberapa nada yang menunjukan perasaan emosional. Suasana yang dibuat seakrab mungkin, karena dengan menciptakan keakraban akan lahir saling pengertian dan hubungan yang harmonis, 6. (I) Instrumentalities atau saluran yang digunakan dalam berkomunikasi adalah bahasa Minangkabau baik verbal non vokal, non verbal. 7. (N) Norm, Norma berkaitan dengan kaidah komunikasi atau aturan yang mengatur tradisi Marosok sangat ditentukan oleh adat Minangkabau dan Agama Islam, dan 8. (G) Genre atau tipe peristiwa komunikatif yang terjadi dalam tradisi marosok adalah cerita, tanya jawab dan nasihat.

Pola hubungan antar komponen-kompenen komunikasi yang membentuk pola komunikasi tradisi marosok antara sesama penjual dalam budaya dagang minangkau merupakan pola yang dibentuk atas dasar kesadaran untuk menjaga silaturahmi melalui forum diskusi antara sesama pedagang, keharusan mewariskan nilainilai penting dalam berdagang, dan keharusan membantu sesama. Berdasarkan itu semua semua penjual berpartisipasi aktif menuangkan semua pengalaman yang didapatkan selama bertransaksi dan kemudian dibagi ke forum. Setiap orang di forum memberikan pendapat masing-masing dan menarik kesimpulan. Kesimpulan inilah yang kemudian digunakan sebagai landasan bertindak dalam berdagang di kemudian hari.

Berdasarkan simpulan dari penelitian maka peneliti memberikan saran sebagai berikut: sebaiknya, masyarakat terus melestarikan kebudaya ini karena akan menjadi salah satu ciri khas kajian komunikasi budaya, dan sebaiknya, pemerintah memberikan perhatian lebih terhadap tradisi ini agar tetap lestari. Mengingat bahwa semakin banyaknya pengaruh globalisasi dan transparasi yang bisa jadi membuat budaya ini lama kelamaan hilang.

\section{DAFTAR PUSTAKA}

Brislin.(1993). Understanding culture's influece on behavior. Fort Worth, TX: Harcourt Brace Javanovich

Charon, J. M, \& Vigilant, L. G. (2009). The meaning of sociology: A Reader, edisi 9. Upper Saddle River: Pearson.

Curtis, Et All. (2005). Komunikasi bisnis dan profesional. Bandung: Remaja Rosdakarya

Fahlevi, M, A. (2015). Komunikasi non verbal dalam pekan ternak "marosok" di payakumbuh, provinsi sumatera barat. e-Proceeding of Management: Vol.2, No.3 Desember 2015. ISSN: 2355-9357

Ferraro, G. (2008). Cultural anthropology an applied perspective, edisi ke-7. Thomson Wadsworth

Hall, S. (1990). Cultural identity and diaspora. London: Rutherford

Hakimy, I. (1994). Rangkaian mustika adat basandi syarak di minangkabau. Bandung: Remaja Rosda Karya

Hamami, T., Sinaga, D., \& Erwina, W. (2014). Perilaku pencarian informasi sebagai sumber gagasan pembuatan berita oleh wartawan pikiran rakyat. Jurnal Kajian Informasi \& Perpustakaan, 2(2), 111-120

Hymes, D. (1972). Models of the interaction of languege and social life. New York: Holt, Rinehart \& Winston

Kongres Kebudayaaan Minangkabau. (2010), Ajaran, kelembagaan, akhlak, dan kebijakan adat basandi syarak, syarak basandi kitabullah syarak mangato adat mamakai, alam takambang jadi guru untuk seluruh keluarga besar minangkabau di ranah minang dan di rantaudalam konteks negara kesatuan republik indonesia

Kuswarno, E. (2012). Etnografi komunikasi. Bandung: Widya Padjadjaran

Moleong, J. L. (2002). Metode penelitian kualitatif. Bandung: Remaja Rosdakarya

Morreale, S, dkk. (2007). Human communication: motivation, knowledge, and skill, edisi 2. Belmoth, CA: Thomson Wadworth 
Mulyana,D.(2012).Pengantarilmukomunikasi. Bandung: Remaja Rosda Karya

Nurtyasrini, S. \& Hafiar, H. (2016). Pengalaman komunikasipemulungtentangpemeliharaan kesehatan diri dan lingkungan di tpa bantar gebang. Jurnal Kajian Komunikasi, 4/2(8), 219-228

Pandoe, M. D. (2010). Jernih melihat cermat mencatat. Jakarta: Kompas

Supratman, L. P. \& Rafiqi, A. (2016). Kajian etnografi komunikasi pada gaya berkomunikasi komunitas. Jurnal Kajian Komunikasi, 4/1, 1-9

Purwanto, D. (2006). Komunikasi bisnis edisi ketiga. Jakarta: Erlanggga

Samovar, L. A, dkk. (2014). Komunikasi lintas budaya Edisi 7. Jakarta: Salemba Humanika

Samovar, P. R. E. ( 2009). Intercultural communication; a reader, Edisi 12 . Belmont, CA: Wadsworth

Utamidewi, W., Mulyana, D., \& Rizal, E. (2017). Pengalaman komunikasi keluarga pada mantan buruh migran perempuan. Jurnal Kajian Komunikasi, 5/1, 69-80

Wood, J. T. (2013). Komunikasi teori dan praktek. Salemba Humanika

Wood, J. (2009). Comunication in our live, edisi ke-5 Belmont, CA: Wadsworth 